\title{
The Influence of Brand Loyalty on Cosmetics Buying
}

\section{Behavior of UAE Female Consumers}

\author{
Dr. Hamza Salim Khraim \\ Marketing Department, Faculty of Business \\ Middle East University, Amman, Jordan \\ E-mail: hkhraim@meu.edu.jo
}

Received: January 24, 2011 Accepted: February 9, 2011 doi:10.5539/ijms.v3n2p123

\begin{abstract}
The worldwide annual expenditures for cosmetics is estimated at U.S. \$18 billion, and many players in the field are competing aggressively to capture more and more markets. The purpose of this article is to investigate the influence of brand loyalty on cosmetics buying behavior of female consumers in the Emirate of Abu Dhabi in the UAE. The seven factors of brand loyalty are brand name, product quality, price, design, promotion, service quality and store environment. Questionnaires were distributed and self-administered to 382 respondents. Descriptive analysis, one-way ANOVA and Pearson Correlation were used in this study. The findings of this study indicated that brand name has shown strong correlation with brand loyalty. The research results showed that there is positive and significant relationship between factors of brand loyalty (brand name, product quality, price, design, promotion, service quality and store environment) with cosmetics brand loyalty.
\end{abstract}

Keywords: Female buying behavior, Brand loyalty, Cosmetics, UAE

\section{Introduction}

The history of cosmetics spans at least 6,000 years of human history, and almost every society on earth. In the Western world, the use of cosmetics became prominent in the middle ages, typically among members of the upper classes. Although it is generally believed that cosmetics as they are now known originated in the Far East, the study of non-industrial cultures indicates the use of cosmetics in every part of the world. The war paint of native Americans, the tattooing and scarification (making of superficial incisions of the skin) practiced by many peoples (the Maori of New Zealand and numerous African cultures, for instance), and the use of woad (a plant dye used by ancient Britons to paint their bodies blue) are all forms of cosmetic used for psychological intimidation of the enemy as well as adornment (Draelos, 2007). The general term cosmetics is applied to all preparations used externally to condition and beautify the body, by cleaning, coloring, softening, or protecting the skin, hair, nails, lips, or eyes. The U.S. Food and Drug Administration (FDA), which regulates cosmetics in the United States, defines cosmetics as products "intended to be applied to the human body for cleansing, beautifying, promoting attractiveness, or altering the appearance without affecting the body's structure or functions." This broad definition includes any material intended for use as a component of a cosmetic product. The FDA specifically excludes soap from this particular category.

Of the major firms, the oldest and the largest is L'Oréal, was founded by Eugene Schueller in 1909 as the French Harmless Hair Coloring Company. The market was developed in the United States during the 1910s by Elizabeth Arden, Helena Rubinstein, and Max Factor. These firms were joined by Revlon just before World War II and Estée Lauder just after (Mayell, 2004). The growth of cosmetics and beauty products markets have surged significantly as consumers are increasingly becoming aware about appearance, beauty, grooming and choice of personal care products. According to Whittaker (2007) there are more than 3,300 companies manufacturing and distributing cosmetic and skin care products in the United States alone.

\subsection{Research Significance and Objectives}

In the UAE, the beauty and cosmetics sector is experiencing unprecedented growth. Recent statistics reveal a category growth of 12 per cent annually and market value of $\$ 1.7$ billion, which is expected to exceed $\$ 2.1$ billion this year (Chaudhry, 2008). This study will contribute towards a better understanding of the aspects of 
consumer buying behavior in this lucrative sector in the UAE. This type of study is crucial to delineate the new trends in the UAE Muslim society. As we will see below, the country in general experience a rapid growth and modernization where more women's are involved in business coupled with a massive movement among young generation towards using the fashion and cosmetics to cope with this social and cultural changes. These new trends give more attention for personal appearance especially among new educated young generation and based on that, the researcher chooses respondent age between 16-42 years.

This study will enrich and add more to the trivial literature and provides useful information on Abu Dhabi society to the business sector of this Emirate as well as dealers in the retailing sectors. This information should be of valuable use to marketers to identify marketing opportunities to ensure greater efficiency in their use of resources and other efforts, which directly related to consumer purchasing behavior such as market segmentation, consumer targeting, product features, promotional and selling efforts. Based on the above, the objectives of this paper are to:

Provide an overview of cosmetics market in the UAE and its importance.

Examine the influence of brand loyalty on female buying behavior of cosmetics

\section{Literature review}

\subsection{Overview on the Emirate of Abu Dhabi}

Abu Dhabi is the capital and the second largest city in the United Arab Emirates. The city had an estimated population of 869,751 in 2009. Abu Dhabi has grown to be a cosmopolitan metropolis. Its rapid development and urbanization, coupled with the relatively high average income of its population, has transformed Abu Dhabi, making the city more Westernized than most other Arab cities. Today the city is the country's center of industrial activities, and a major cultural, and commercial centre due to its position as the capital. Abu Dhabi alone generates 15\% of the GDP of the United Arab Emirates (Gulf news, 2009). Peoples buying behavior is heavily influenced by the values, norms, and expectations of Islam. Abu Dhabi social structure involves strong kinship patterns and the clan is the basis of Abu Dhabi tribal society. The extended family is the foundation of rural and urban society, and thus there is a strong sense of loyalty to the clan or family. Therefore, one can imagine the intensive social interaction that takes place in Abu Dhabi and its impact on Emirates buying behavior.

\subsection{Cosmetics Market in the UAE}

It is estimated that Emirate women alone spend close to AED 1 billion (US \$272 million) per year on beauty products and treatments (Mena Report 2009). In recent years, working women with high disposable income spend more on cosmetics and beauty products and particularly international brands, which are more popular in the UAE. According to Retail International, retail accommodation for beauty product retailers has grown $30 \%$ in the last three years to account for $25-30 \%$ of all retail space in the UAE. According to Chaudhry (2008) the cosmetics market value $\$ 1.7$ billion, which is expected to exceed $\$ 2.1$ billion by next year.

This rapid growth in cosmetics sales and market in the UAE grabs the attention of beauty and skin care companies throughout the World. Paris Gallery, which has 26 outlets and controls around $60 \%$ of high-end cosmetics and fragrance sales in the UAE, is expected to see growth of more than $20 \%$ per year. Paris Gallery is planning to open another 40 retail outlets within its existing UAE, Qatar and Saudi Arabia base as well as Bahrain, Kuwait and Oman. Major brands are very active and more of the key suppliers are expected to follow such as Christian Dior and Coty. The market's growth is also attributed to the region's demographics, with a population of young, fashionable trendsetters with high disposable income (Abed Al Aziz, 2006). Due to the lack of local cosmetics manufacturers, most of companies selling cosmetics in the UAE are European and American (Cochrane, 2006). Due to this reason, the Emirates want to attract manufacturers and multinational firms to the newly established Jebal Ali Free Zone Authority's Fragrance Beauty and Fashion Park to give the UAE a greater regional role in the growing market.

\subsection{Brand Loyalty}

Howard and Sheth's theory of buyer behavior (1969) were the first to introduce the notion of brand consideration into marketing. Brand loyalty is defined as keeping preferable to a specific product or service (BNET Business Dictionary). Aaker and Keller, 1990 believe that loyalty is closely associated with various factors, one of the main ones being the experience of use. Customers may be loyal owing to high switching barriers related to technical, economical or psychological factors, which make it costly or difficult for the customer to change. In another point of view, customers may also be loyal because they are satisfied with the brand, and thus want to continue the relationship (Fornell, 1992). 


\subsection{Factors of Brand Loyalty}

Research has indicated that brand attributes are viewed as important elements in a consumer's decision-making. For example, Lau et al. (2006) in his article mentioned that there were seven factors that influenced consumers' brand loyalty towards certain brands. The factors were brand name, product quality, price, Design, store environment, promotion and service quality.

\subsubsection{Brand Name}

Famous brand names can disseminate product benefits and lead to higher recall of advertised benefits than non-famous brand names (Keller, 2003). There are many unfamiliar brand names and alternatives available in the market place. Consumers may prefer to trust major famous brand names. These prestigious brand names and their images attract consumers to purchase the brand and bring about repeat purchasing behavior and reduce price related switching behaviors (Cadogan and Foster, 2000). Furthermore, brand personality provides links to the brand's emotional and self-expressive benefits for differentiation. This is important for brands, which have only minor physical differences and consumed in a social setting where the brand can create a visible image about the consumer itself.

According to Kohli and Thakor (1997), brand name is the creation of an image or the development of a brand identity and is an expensive and time consuming process. The development of a brand name is an essential part of the process since the name is the basis of a brand's image. Brand name is important for the firm to attract customers to purchase the product and influence repeat purchasing behavior. Consumers tend to perceive the products from an overall perspective, associating with the brand name all the attributes and satisfaction experienced by the purchase and use of the product.

As was a resident of the UAE, the researcher was able to detect that the consumption pattern in the Emirate of Abu Dhabi, is marked by great demand for various imported products and services. This is due to the belief that foreign products are superior to their local counterparts.

\subsubsection{Product Quality}

Product Quality encompasses the features and characteristics of a product or service that bears on its ability to satisfy stated or implied needs. In other words, product quality is defined as "fitness for use" or "conformance to requirement" (Russell and Taylor, 2006). Consumers may repeat the purchase of single brands or switch around several brands due to the tangible quality of the product sold. Material is important in product quality because it affects the hand feel, texture and other performance aspects of the product. Further, consumers relate personally to color, and could select or reject a product because of color. If the color does not appeal to them or flatter their own color, they will reject the product. Functional attributes in cosmetics include quick-dry, breathable, waterproof, lightweight, and finally, durability. For instance, some consumers use cosmetics for work and some for leisure and sports, as they need a lot of movement, while durability is an important consideration in purchasing cosmetics. Perfectionist or quality consciousness is defined as an awareness of and desire for high quality products, and the need to make the best or perfect choice versus buying the first product or brand available (Sproles and Kendall, 1986). This indicates that quality characteristics are also related to performance.

\subsubsection{Price}

According to Cadogan and Foster (2000), price is probably the most important consideration for the average consumer. Consumers with high brand loyalty are willing to pay a premium price for their favored brand, so, their purchase intention is not easily affected by price. In addition, customers have a strong belief in the price and value of their favorite brands so much so that they would compare and evaluate prices with alternative brands (Keller, 2003). Consumers' satisfaction can also be built by comparing price with perceived costs and values. If the perceived values of the product are greater than cost, it is observed that consumers will purchase that product. Loyal customers are willing to pay a premium even if the price has increased because the perceived risk is very high and they prefer to pay a higher price to avoid the risk of any change (Yoon and Kim, 2000). Long-term relationships of service loyalty make loyal customers more price tolerant, since loyalty discourages customers from making price comparison with other products by shopping around. Price has increasingly become a focal point in consumers' judgments of offer value as well as their overall assessment of the retailer (De Ruyter et al., 1999). Price communicates to the market the company's intended value positioning of its product or brand. Price consciousness is defined as finding the best value, buying at sale prices or the lowest price choice (Sproles and Kendall, 1986).

\subsubsection{Design}

Design is visual appearance, which includes line, shape and details affecting consumer perception towards a 
brand (Frings, 2005). Brands that supply stylish package attract loyal consumers who are fashion conscious. Fashion leaders or followers usually purchase or continue to repeatedly purchase their products in stores that are highly fashionable. They gain satisfaction from using the latest brands and designs which also satisfies their ego.

A research conducted by Duff (2007) investigated the niche market in women's cosmetics, and the results showed that cosmetics buyers were becoming more fashion conscious and were demanding products with more attractive design; furthermore, consumers have a tendency to use different makeup designs for different occasions. According to Sproles and Kendall (1986), fashion consciousness is generally defined as an awareness of new designs, changing fashions, and attractive styling, as well as the desire to buy something exciting and trendy.

\subsubsection{Store Environment}

Omar (1999) emphasized that the store environment was the single most important factor in retail marketing success and store longevity. Positive attributes of the store, which include store location, store layout, and in-store stimuli, affect brand loyalty to some extent. Store location and number of outlets are crucial in altering consumer shopping and purchasing patterns. If consumers find the store to be highly accessible during their shopping trip and are satisfied with the store's assortment and services, these consumers may become loyal afterwards (Lovelock, 2010). Thus, a store's atmosphere is one of the factors that could influence consumer's decision-making.

The stimuli in the store, such as the characteristic of other shoppers and salespeople, store layout, noises, smells, temperature, shelf space and displays, sign, colors, and merchandise, affect consumers and serve as elements of product attributes, which may in turn, affect consumer decision making and satisfaction with the brand (Lovelock, 2010). On the other hand, background music played in the stores affects attitudes and behavior. The slow-beat musical selection leads to higher sales volume as consumers spend more time and money in a conducive environment. Research conducted by Lin and Chang (2003) showed that the channel convenience of the brands had significant influence on buying behavior. This means that the accessibility to this product/brand in the store is important when purchasing low involvement products. Consumers will not go to another store just to find the brand. Instead, they will stay put and choose another brand.

\subsubsection{Promotion}

Promotion is a marketing mix component, which is a kind of communication with consumers. Promotion includes the use of advertising, sales promotions, personal selling and publicity. Advertising is a non-personal presentation of information in mass media about a product, brand, company or store. It greatly affects consumers' images, beliefs and attitudes towards products and brands, and in turn, influences their purchase behaviors (Lovelock, 2010). This shows that promotion, especially through advertising, can help establish ideas or perceptions in the consumers' minds as well as help differentiate products against other brands. According to Clow (2010), promotion is an important element of a firm's marketing strategy. Promotion is used to communicate with customers with respect to product offerings, and it is a way to encourage purchase or sales of a product or service. Sales promotion tools are used by most organizations in support of advertising and public relations activities, and they are targeted toward consumers as final users.

\subsubsection{Service Quality}

A common definition of service quality is that the service should correspond to the customers' expectations and satisfy their needs and requirements (Lovelock, 2010). Service quality is a kind of personal selling, and involves direct interactions between salespeople and potential buyers. Consumers like to shop at specific stores because they like the services provided and are assured of certain service privileges.

The impact of salespeople-consumer relationships will generally result in long term orientation of consumers towards the store or brand. Trust in salespeople appears to relate to overall perceptions of the store's service quality, and results in the consumer being very satisfied with the stores in the end. Additionally, personalization (i.e. reliability, responsiveness, personalization and tangibles) significantly influence consumers' experience and evaluation of service, and in turn, affects the brand loyalty of consumers (To and Leung, 2001). Gronroos (1990) noted that the quality of a service as perceived by customers had three dimensions: functional (or process) dimension, technical (or outcome) dimension, and image. Furthermore, Richard and Allaway (1993) argued that utilizing only functional quality attributes to explain and/or predict consumers' behavior might be a misspecification of service quality and had low predictive validity.

\section{Empirical Research}

According to Al-Ashban and Burney (2001) cosmetics buying behavior literature in developing countries in 
general is inadequate and ambiguous. Al-Ashban and Burney (2001) was the only study conducted in the Middle East and about cosmetics use among women in Saudi Arabia. The results of this study suggest that education and social status of Saudi Arabian women play a vital role in their trend to use cosmetics. In addition, the study revealed a strong significance of predictors of usage habits namely; age, income levels, occupation, and marital status with respect to longevity of exposure; and of body color, allergic, occupation and marital status with obsessions.

While the aim of Ben Amour (2009) research was to determine the effectiveness of product sampling in terms of usage in the cosmetics industry and to draw a consumer profile who is reactive to free samples and to determine product characteristics that would lead to free samples usage. To accomplish those objectives, samples were given away to 500 women. Results of this research shows that launching product sampling campaigns is quite effective as free samples usage appears to be high (72 per cent). Companies should give away samples of new products. They also should offer samples of product types with a high-penetration rate. In addition, it is better to sample well-known brands rather than unknown ones. Moreover, the authors recommend targeting family brand users when offering free samples. Finally, it is not profitable to target consumers with low-annual spending within the product category.

Another study by Guthrie et al. (2008) who examines women's perceptions of brand personality in relation to women's facial image and cosmetic usage. The study seeks to develop a better understanding of how various factors influence perceptions of cosmetic brands in the USA. The survey included items measuring facial image, cosmetic usage, brand personality, and brand attitude. The findings show that brand personality of competence found to be important across all three brands, consumer perceptions pertaining to the remaining brand personality traits differed. The study found that consumers' facial image influenced the total quantity of cosmetics used. Results also indicate that a relationship exists between facial image and brand perceptions.

\subsection{Hypotheses}

This article focuses on the factors that influence consumers' brand loyalty towards a particular brand. Based on the factors that influence brand loyalty, the following hypotheses are derived.

H1: There is a significant and positive relationship between brand name of cosmetics and brand loyalty.

$\mathrm{H} 2$ : There is a significant and positive relationship between cosmetics quality and brand loyalty.

H3: There is a significant and positive relationship between cosmetics price and brand loyalty.

$\mathrm{H} 4$ : There is a significant and positive relationship between cosmetics design and brand loyalty.

H5: There is a significant and positive relationship between promotion and brand loyalty of cosmetics.

H6: There is a significant and positive relationship between service quality and brand loyalty of cosmetics.

H7: There is a significant and positive relationship between store environment and brand loyalty of cosmetics.

\subsection{Research Methodology}

A questionnaire was developed and pilot tested through personal interviews with five senior level professionals at Paris Gallery, the most famous cosmetics outlet in UAE. The questionnaire contained two sections: the first section about consumers' demographics and the second section about brand loyalty factors. The survey was carried out on a random sample of 382 female cosmetics consumers aged between 16 to 42 . The survey was distributed at Abu Dhabi city at three malls namely; Abu Dhabi mall, Marinah mall, Madinat Zayed Shopping Centre, in addition to Paris Gallery and it took two months. A total of 382 usable questionnaires were returned and collected $58 \%$ response rate.

Table 1 shows that age composition of those whose ages were between 16-24 years were $23 \%$ of the respondents, whereas almost half (49\%) of the respondents ages ranged between $25-33$ years. About $28 \%$ of the respondents ranged between $34-42$ years old. In other words, approximately $72 \%$ of the respondents fell below 33 years of age. Interestingly, the sample was almost balanced between married $52 \%$, and the unmarried $48 \%$ respondents. The education profile of the surveyed respondents indicates that $70 \%$ of the respondents had undergraduate degree and $20 \%$ with high school and only $10 \%$ had postgraduate degrees. About $29 \%$ of the respondents earned less than DH 10000 a month, 51\% of them earned between DH 10000 and 20000, and 20\% more than 20001 .

\subsection{Data Analysis}

In this study, ANOVA is used to determine whether there is any significant relationship between independent variables (brand name, product quality, price, design, promotion, service quality and store environment) and income and age of the respondents. ANOVA is an appropriate test for hypothesis testing when there are more 
than two groups measured on an interval scale. While One-way ANOVA is a single-factor, fixed-effects model to compare the effects of one factor (Malhotra, 2007). This means that One-way ANOVA is used to determine the variability of the sample values by looking at how much the observation within each group varies as well as how much the group means varies. Pearson Correlation was seen as appropriate to analyze the relationship between the two variables, which were interval-scaled and ratio-scaled. Furthermore, correlation coefficients reveal magnitude and direction of relationships, which are suitable for hypothesis testing (Malhotra, 2007). The researcher used Pearson correlation to test seven independent variables (brand name, product quality, price, design, promotion, service quality and store environment) that influenced consumer brand loyalty and to test if a relationship existed between the independent and dependent variables.

\section{Results}

\subsection{Reliability and Validity}

Table 2 lists the Cronbach's Alpha (coefficient alpha) of each variable. All the variables show a high degree of reliability. Table 3 shows that there were seven independent variable factors of brand loyalty that were tested by the researcher through the questionnaires distributed to respondents. The Likert scale was used in the questionnaire: 1 indicates strongly disagree, 2 indicates disagree, 3 indicates neutral, 4 indicates agree and 5 indicates strongly agree. The result is derived from the highest mean score of factors of brand loyalty based on the respondents' answers. The overall result shows that product quality is the most important factor. In the UAE environment respondents particularly choose product quality as the main factor that influences them to be brand loyal customers. One-Way ANOVA analysis between the factors of brand loyalty and income level was executed. The objective of the analysis is to find out whether there is significant relationship between the variables. The results of the analysis are presented in Table 4 . There are four variables that are significant which are brand name (.000), product quality (.009), promotion (.004) and service quality (.038). The overall results show that UAE consumers prefer brand name, product quality, promotion and service quality as factors of brand loyalty. In Table 5 , only two variables are significant which are brand name (.050) and price (.014). Overall results show that among the three age categories, females ages between 34 to 42 favor brand names more compared to the other age categories.

\subsection{Hypothesis Test}

As shown in Table 6, brand name was found to have significant positive relationship with brand loyalty. The research results showed that consumers favored brand image when they perceive positive benefits or function from the product. They would then recommend the brand, have positive reaction on the price premium and are willing to accept brand extensions to other product categories within the same brand. Product quality was shown to have positive relationship with brand loyalty.

The correlation between these two variables is shown in Table 5. The correlation is considered a moderate correlation $(\mathrm{r}=0.302)$ based on Cohen's (1988) guidelines. This finding indicates that product quality is significant in the consumer decision making process. The research findings showed that price and brand loyalty had a positive relationship. Price was an important consideration for the average consumer. However, consumers with high brand loyalty were less-price sensitive. The result suggested that as long as the respondents were satisfied with a particular brand, they would repurchase the product with the same brand name even if it was highly priced. However, the findings showed that there was no relationship between design and brand loyalty. From the seven variables identified, design was not considered an important factor for UAE consumers to be loyal to particular cosmetics brand.

The results showed that promotion and brand loyalty were positively related. Promotion was considered as one of the most important factors in determining a consumers' brand loyalty. It includes the use of advertising, sales promotion, personal selling and publicity. From the study conducted, it was seen that female respondents actually spent more time reading product labels before buying products. The finding also showed that service quality and brand loyalty had a positive relationship. Service quality was an important factor in influencing and encouraging consumers to patronize a store. The results indicated that the salesperson-consumer relationship will generally result in long-term orientation of consumers toward a store. At the same time, trust in the salesperson appeared to relate to the overall perception of the store's service quality which resulted in the consumer's total satisfaction with the store. Store environment was positively related to brand loyalty. The Store environment is considered one of the factors that can influence consumer brand loyalty. From this study, it is observed that consumers paid much attention to store attributes such as merchandise display, variety of selection, parking space, easily accessible by car and the reputation of the store in purchasing products. 


\section{Conclusions}

This research has provided insights into female consumer buying behavior in the Emirate of Abu Dhabi. Marketers agree that developing an understanding of target customers and segments are important inputs in differentiating products and enhancing selling propensity. The purpose of this research is to investigate how the respondents are influenced by factors of brand loyalty towards cosmetics brands. Brand loyalty is important for an organization to ensure that its product is kept in the minds of consumers and prevent them from switching to other brands. The research showed that it was not easy to obtain and maintain consumer loyalty for a company's product because there were many forces drawing consumers away such as competition, consumers' thirst for variety, etc. From the analysis of this study, it was shown that there are six factors of brand loyalty that were appropriate in the UAE environment which are, the brand name, product quality, price, promotion, service quality and store environment.

The findings revealed that product quality plays a significant role in influencing consumers to be brand loyal customers. Additionally, the overall findings of this study also show that amongst others UAE consumers prefer brand name, product quality, price, promotion, store environment and service quality as relevant factors attributable to brand loyalty. All these factors showed positive relationships with brand loyalty except design which had no relationship. Undeniably, the cosmetics industry is one area, which offers vast potential in the consumer market where there is increase in social activities. More reliable and positive findings on this topic would impact on consumers, marketers and policy makers.

The results obtained from this study are similar to some other different studies conducted in this field. For example, the results of Wong and Yahyah (2008) on the Influence of Brand Loyalty on Consumer Sportswear were similar to our study. The Results of Shaharudin (2010) study goes along with this study in terms of the relationship between extrinsic attributes of product quality with brand loyalty.

Finally, marketers should find it useful to understand how loyalty factors can affect consumer-buying behavior in the marketplace, which can help in segmenting consumers and markets for their brands and marketing communication. By examining how cosmetic usage determines brand perceptions, companies can improve their marketing strategies to enhance customer satisfaction and increase their customer base. Moreover, by identifying the brand personalities that attract consumers, companies can pinpoint the characteristics customers look for in a product, which in turn can be used to enhance brand image.

\subsection{Future Research}

It is highly recommended for future research to expand the span of attributes that affects brand loyalty, as well as to study more products and services in order to get an in depth and more clear picture about real relationship between the different product/service attributes and brand loyalty.

\section{References}

Aaker, D., \& Keller, K. L. (1990). Consumer Evaluations of Brand Extensions. Journal of Marketing, 54(1), 27-41.

Abed Al Aziz, N. (2006). Appearance value in the Middle East, TDC trade, Date 16 May. [Online] Available: www.tdctrade.com/imn/06051603/cosmetics033.htm.

Al-Ashban, A., \& Burney, M. (2001). Key antecedents to cosmetics use among women in Saudi Arabia: Empirical evidence from Saudi Arabia. JISSM, 9, 3- 20.

Ben Amor, Insaf., \& Francis G. (2009). Influences on free samples usage within the luxury cosmetic market. Direct Marketing: An International Journal, 3(1), 67 - 82.

Business Definition Brand Loyalty. [Online] Available:
http://dictionary.bnet.com/definition/Brand+Loyalty.html?tag=col1;rbDictionary (8Apr.2009).

City Mayors. (2009). Cost of living the world's most expensive cities. [Online] Available: http://www.citymayors.com/ features/cost_survey.html. (Retrieved 2009-07-22.).

Clow, M. (2010). Integrated Marketing Communications. Pearson Education, Inc. publishing as Prentice Hall.

Chaudhry, M. D. (2008). Cosmetic industry achieves big growth in the region. Khaleej Times, 22 April.

Cadogan, J. W., \& Foster, B. D. (2000). Relationship Selling and Customer Loyalty: An Empirical Investigation, Marketing Intelligence and Planning, 18(4), 185-199.

Draelos, Z. D. (2007). [Online] Available: http://www.emedicine.com/derm/topic502.htm (Feb 16). 
De Ruyter, K., Wetzels, M., \& Van Birgelen, M. (1999). How Do Customers React to Critical Service Encounters: A Cross-sectional Perspective. Total Quality Management, 10(8), 1131-1145.

Duff, M. (2007). Niche Marketing of cosmetics. DSN Retailing Today, 38, 29-35.

Fornell, C. (1992). A National Customer Satisfaction Barometer: The Swedish Experience. Journal of Marketing, 56(Jan), 6-21.

Frings, G. S. (2005). Fashion: From Concept to Consumer (8th Ed.). New Jersey: Pearson/Prentice Hall.

Giunipero, L., \& Daniel J. F. (2001). Purchasing practices in Saudi Arabia - an exploratory analysis. International Journal of Physical Distribution \& Logistics Management, 31, 686-704.

Guthrie, M., Hye-Shin, K., \& Jaehee, J. (2008). The effects of facial image and cosmetic usage on perceptions of brand personality. Journal of Fashion Marketing and Management, 12(2), 164-181.

Gulfnews. (2009). Abu Dhabi and Dubai lead in contributions to GDP. Web.dcci.ae. Retrieved on 2009-07-16.

Howard, J. A., \& Sheth, J. N. (1969). The Theory of Buyer Behavior, New York: John Willy \& Sons.

Kohli, C. \& Thakor, M. (1997). Branding Consumer Goods: Insights from Theory and Practice, Journal of Consumer Marketing, 14(3), 206-219.

Keller, K. L. (2003). Strategic Brand Management: Building, Measuring and Managing Brand Equity. New Jersey: Prentice Hall.

Linda Moore. (2007). [Online] Available: http://cosmeticsuniverse.com

Lau, M. M., Chang, M. S., Moon, K., \& Liu, W. S. (2006). The Brand Loyalty of Sportswear in Hong Kong, Journal of Textile and Apparel. Technology and Management, 5, 1-13.

Lovelock, C. H. (2010). Services Marketing, $\left(4^{\text {th }}\right.$ ed), New Jersey: Prentice Hall.

Lin, M. Y., \& Chang, L. H. (2003). Determinant of Habitual Behavior for National and Leading Brand in China, Journal of Product and Brand Management. 12(2), 94-107.

Marcoux, J. S. (1997). The attitudes underlying preferences of young urban educated polish consumers towards products made in western countries. Journal of International Consumer Marketing. 9(4), 5-29.

Mayell, H. (2004). As Consumerism Spreads, Earth Suffers, Study Says. National Geographic online. Retrieved September 11, 2008

MMR. (2000). Mass market retailers woo growing teen market, 7 (15), 41.

Meyer, P. (2001). Brands need to understand mindset of echo-boomers in order to survive. Kids Marketing Report, 1(28), 14.

Meneely, L., Amy, B., \& Chris, S. (2009). International Journal of Retail \& Distribution Management. 37(12), $1041-1056$.

Mena Report. (2009). [Online] Available: www.menareport.com.

Malhotra, N. K. (2007). Marketing Research: An Applied Orientation $\left(5^{\text {th }}\right.$ ed). New Jersey: Pearson Prentice Hall.

Omar, O. E. (1999). Retail Marketing. Harlow: Pearson Education.

Cochrane, P. (2006). Middle East - The middle ground, Country Survey, SPC June.

Robert, D. (2007). Demand for perfume and cosmetics in the Gulf. Gulf news /21 May.

Rayan, K. (2002). Cosmetics market is booming. Business Today, 19-5-2002.

Russell, R. S., \& Taylor, B. W. (2006). Operation Management: Quality and Competitiveness in a Global Environment $\left(5^{\text {th }}\right.$ ed). New Jersey: John Wiley \& Sons, Inc.

Sproles, G. B., \& Kendall, E. L. (1986). A methodology for profiling consumer decision -making design. The Journal of Consumer Affairs, 20, 267-279.

Sproles, E. K., \& Sproles, G. B. (1990). Consumer decision-making designs as a function of individual learning designs. The Journal of Consumer Affairs, 24(1), 134-147.

Shaharudin, M. R., Anita, A., Suhardi, W., Shamsul, J., Etty, H., \& Nurazila, A. (2010). The Relationship Between Extrinsic Attributes of Product Quality with Brand Loyalty on Malaysia National Brand Motorcycle/Scooter. Canadian social science, 6, 170-182. 
Wong, f. Y., \& Yahyah, S. (2008). Influence of Brand Loyalty on Consumer Sportswear. Int. Journal of Economics and Management, 2, 221-236.

Whittaker, K. (2007). [Online] Available: http://cosmeticsuniverse.com/.

Yoon, S. J., \& Kim, J. H. (2000). An Empirical Validation of a Loyalty Model based on Expectation and Disconfirmation. Journal of Consumer Marketing, 17(2), 120-136.

Table 1. Sample Description of Demographics

\begin{tabular}{|l|c|c|}
\hline & Frequency & $\%$ \\
\hline Age: & & \\
$16-24$ & 88 & 23 \\
$25-33$ & 187 & 49 \\
$34-42$ & 107 & 28 \\
\hline Marital Status: & & \\
Married & 186 & 48 \\
Unmarried & 196 & 52 \\
\hline Education: & & \\
High school & 78 & 20 \\
Undergraduate & 267 & 70 \\
Postgraduate & 35 & 10 \\
\hline Income: & 77 & 29 \\
3000-10000 & 196 & 51 \\
10001- 20000 & 109 & 20 \\
More than 20001 & & \\
\hline
\end{tabular}

Table 2. Reliability Analysis of Factor of Brand Loyalty

\begin{tabular}{|cc|}
\hline Variables & Alpha \\
\hline Brand name & 0.7028 \\
Product Quality & 0.6572 \\
Price & 0.6618 \\
Design & 0.7482 \\
Promotion & 0.6974 \\
Service Quality & 0.8200 \\
Store Environment & 0.7139 \\
Brand Loyalty & 0.6646 \\
\hline
\end{tabular}


Table 3. Ranking Factor of Brand Loyalty

\begin{tabular}{|c|c|c|}
\hline Factors of Brand Loyalty & Rank & Mean \\
\hline Product Quality & 1 & \\
\hline Q1. The brand last longer than other brands & & 3.69 \\
\hline Q2. The materials used by the brand are natural & & 4.11 \\
\hline Q3. The brand has sufficient color & & 3.65 \\
\hline \multirow[t]{2}{*}{ Q4. The brand has good functional quality } & & 3.77 \\
\hline & & Mean Average 3.80 \\
\hline Design & 2 & \\
\hline Q1. The brand provides wide variety of designs & & 3.72 \\
\hline Q2. Designs of the brand are suitable for me & & 3.79 \\
\hline Q3. Designs of the brand have distinctive features & & 3.73 \\
\hline \multirow[t]{2}{*}{ Q4. Designs of the brand are trendy and fashionable } & & 3.85 \\
\hline & & Mean Average 3.77 \\
\hline Brand Name & 3 & \\
\hline Q1. The brand is reputable & & 3.70 \\
\hline Q2. Brand Name and Image attract me to purchase & & 3.82 \\
\hline Q3. Brand Name is selected regardless of price & & 3.41 \\
\hline \multirow[t]{2}{*}{ Q4. Brand reflects my own personality } & & 3.96 \\
\hline & & Mean Average 3.72 \\
\hline Store Environment & 5 & \\
\hline Q1. The brand has good store location & & 3.65 \\
\hline Q2. The brand has sufficient outlets & & 3.77 \\
\hline Q3. The interior display is attractive & & 3.50 \\
\hline \multirow[t]{2}{*}{ Q4. Color and music inside the store are attractive } & & 3.36 \\
\hline & & Mean Average 3.57 \\
\hline Service Quality & 7 & \\
\hline Q1. Salesperson of the store is well-trained & & 3.22 \\
\hline Q2. Salesperson of the stores willing to help & & 3.39 \\
\hline Q3. Salesperson of the store friendly and courteous & & 3.18 \\
\hline \multirow[t]{2}{*}{ Q4. Salespersons of the stores have neat appearance } & & 3.33 \\
\hline & & Mean Average 3.28 \\
\hline Promotion & 4 & \\
\hline Q1 Ads of the brand is attractive & & 3.64 \\
\hline Q2. Ads of the brand attract me to purchase & & 3.44 \\
\hline \multirow[t]{2}{*}{ Q3. Window displays are attractive } & & 3.62 \\
\hline & & Mean Average 3.56 \\
\hline Price & 6 & \\
\hline Q1. Increases of price not hinder me to purchase & & 2.99 \\
\hline \multirow[t]{2}{*}{ Q2. The brand provides goods value for money } & & 3.51 \\
\hline & & Mean Average 3.25 \\
\hline
\end{tabular}


Table 4. Income Level versus Factors of Brand Loyalty

\begin{tabular}{|llllllll|}
\hline & $\begin{array}{l}\text { Brand } \\
\text { Name }\end{array}$ & $\begin{array}{l}\text { Product } \\
\text { Quality }\end{array}$ & Price & Design & Promotion & $\begin{array}{l}\text { Service } \\
\text { Quality }\end{array}$ & $\begin{array}{l}\text { Store } \\
\text { Environment }\end{array}$ \\
\hline $\begin{array}{l}\text { Sig. } \\
\text { Mean }\end{array}$ & .020 & .005 & .157 & .888 & .014 & .022 & .011 \\
$3000-10000$ & 12.3000 & 14.5500 & 7.0500 & 14.3000 & 10.6000 & 12.8500 & 13.9500 \\
$10001-20000$ & 13.7852 & 16.8500 & 7.6000 & 15.2500 & 10.6500 & 12.6250 & 14.6250 \\
$\begin{array}{l}\text { More than } \\
\text { 20001 }\end{array}$ & 18.5000 & 17.0000 & 7.5000 & 16.0000 & 10.1000 & 13.9000 & 15.2000 \\
\hline
\end{tabular}

Table 5. Ages versus Factors of Brand Loyalty

\begin{tabular}{|llllllll|}
\hline & $\begin{array}{l}\text { Brand } \\
\text { Name }\end{array}$ & $\begin{array}{l}\text { Product } \\
\text { Quality }\end{array}$ & Price & Design & Promotion & $\begin{array}{l}\text { Service } \\
\text { Quality }\end{array}$ & $\begin{array}{l}\text { Store } \\
\text { Environment }\end{array}$ \\
\hline Sig. & .050 & .624 & .000 & .185 & .251 & .122 & .555 \\
$6-24$ & 14.6800 & 15.3000 & 6.5600 & 14.7800 & 10.9800 & 13.5400 & 14.0200 \\
$25-33$ & 13.7941 & 15.1765 & 6.3529 & 15.5882 & 10.3824 & 12.5000 & 14.3529 \\
$34-42$ & 15.0625 & 15.4375 & 7.6250 & 15.1875 & 10.5625 & 13.5000 & 14.0625 \\
\hline
\end{tabular}

Table 6. Significance of brand loyalty factors with brand loyalty

\begin{tabular}{|lcc|}
\hline Variables & Pearson Correlation & Sig. (2-tailed)a \\
\hline Brand name & .561 & .002 \\
Product quality & .304 & .002 \\
Price & .466 & .005 \\
Design & .140 & .162 \\
Promotion & .411 & .006 \\
Service quality & .333 & .001 \\
Store environment & .369 & .010 \\
\hline
\end{tabular}

a Significant at 0.01 level 